\title{
OPEN Author Correction: Probabilistic Movement Models Show that Postural Control Precedes and Predicts Volitional Motor Control
}

\author{
Elmar Rueckert, Jernej Čamernik, Jan Peters \& Jan Babič \\ Correction to: Scientific Reports https://doi.org/10.1038/srep28455, published online 22 June 2016 \\ This Article contains an error in the affiliation list, where an affiliation for Jernej Čamernik is missing. The correct \\ affiliations for Jernej Čamernik are listed below: \\ Department for Automation, Biocybernetics and Robotics, Jožef Stefan Institute, Ljubljana, SI-1000, Slovenia \\ Jožef Stefan International Postgraduate School, Jamova cesta 39, 1000 Ljubljana, Slovenia
}

\begin{abstract}
(c) (i) Open Access This article is licensed under a Creative Commons Attribution 4.0 International License, which permits use, sharing, adaptation, distribution and reproduction in any medium or format, as long as you give appropriate credit to the original author(s) and the source, provide a link to the Creative Commons license, and indicate if changes were made. The images or other third party material in this article are included in the article's Creative Commons license, unless indicated otherwise in a credit line to the material. If material is not included in the article's Creative Commons license and your intended use is not permitted by statutory regulation or exceeds the permitted use, you will need to obtain permission directly from the copyright holder. To view a copy of this license, visit http://creativecommons.org/licenses/by/4.0/.
\end{abstract}

(C) The Author(s) 2020 